UDC $631.415 .2 ; 634.11$

COBISS.SR-ID: 220312076

Original research paper

Acta Agriculturae Serbica, Vol. XX, 40 (2015); 165-171

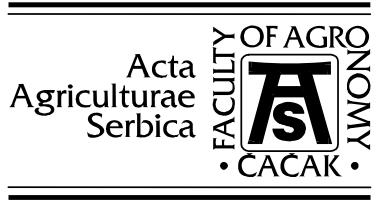

\title{
Effect of high Al content in the soil on vegetative rootstocks for apple
}

\author{
Gorica Paunović, Ljiljana Bosković-Rakočević, Radmila Ilić \\ Faculty of Agronomy, University of Kragujevac, Serbia
}

\begin{abstract}
Proper nutrition of fruit trees depends not only on the availability of major chemical elements in the soil, but also on their inter-relationships, their existing forms in the soil and the capability of the root system to absorb nutrients. The intensity of nutrient uptake is also highly dependent on soil solution $\mathrm{pH}$. In recent years, large areas of land have been increasingly underused for fruit production. This can be partly attributed to soil acidification which also leads to increased concentrations of $\mathrm{H}, \mathrm{Al}, \mathrm{Fe}$ and $\mathrm{Mn}$ ions in its adsorptive complex. In order to neutralize soil acidity and Al toxicity, neutralizing agents should be used to help the soil become capable of fruit production. For this purpose, the following lime materials were used: $\mathrm{CaO}$, bentonite and lifos. The commonly used vegetative rootstocks of different vigor for apple M9, M26 and MM106 were planted as test plants. The impact of lime materials was evaluated with respect to the leaf assimilating surface area, vegetative growth and tree diameter of the rootstocks used. The best soil amending effect was achieved by $\mathrm{CaO}$, followed in declining order by lifos and bentonite.
\end{abstract}

Key words: acid soil, mobile Al, vegetative rootstocks for apple, lime materials 


\section{Introduction}

Proper nutrition of fruit trees depends not only on the supply of major chemical elements in the soil, but also on their relationship, their existing forms in the soil and the capability of the root system to absorb nutrients. The uptake of nutrients from the soil is largely affected by soil $\mathrm{pH}$ value, which is of special importance given the low $\mathrm{pH}$ of a large part of our land, especially in highland areas, where fruit production predominates.

If these soils contain a high concentration of aluminum, usually at a $\mathrm{pH}$ below 5, fruit yields are low or fruit production is even impossible. In addition to aluminum toxicity, such soils have a reduced content of base cations in the soil adsorption complex, mineral (P, Ca, Mg) deficiencies and excess soluble $\mathrm{Mn}$ and Fe (Dugalić, 1997; Radanović and Predić, 1997; Narro et al., 2001; Bošković Rakočević and Bokan, 2002, Sumner, 2004).

Most fruit trees require a $\mathrm{pH}$ of 5.5 to 6.5 for their flourishing because in such soils their root system can develop normally, which is particularly important because they are perennial plantations. Adverse conditions for root development, due to the law of correlation, have a negative impact on the development of the above-ground system, which causes abnormal growth and development of fruit trees (Lučić et al., 1996). At the same time, nutrient uptake in such soils is limited, and very often there are symptoms of nutrient deficiencies, particularly of phosphorus, calcium and magnesium, on leaves and fruits (Ubavić et al., 2001).

In order to neutralize soil acidity and aluminum toxicity, proper liming agents should be used to neutralize the soil and, hence, recover the land for fruit production, and achieve regular and stable yields.

The aim of this study was to investigate possibilities for neutralization of soil acidity and aluminum toxicity using $\mathrm{CaO}$, bentonite and lifos, and test their effects on breeding vegetative rootstocks of differing vigor for apple which are commonly used in the production of apple seedlings.

\section{Materials and methods}

The experiment was set up in vegetative containers filled with the soil obtained from the site Teocin, Mt. Suvobor.

The soil was acidic ( $\mathrm{pH} / \mathrm{KCl} 3.12)$, as determined by the content of $25 \mathrm{mg} /$ $100 \mathrm{~g}$ of mobile aluminum.

To neutralize soil acidity, the following treatments were used:

- Calcium oxide $3.6 \mathrm{t} /$ ha (T1)

- Bentonite $48 \mathrm{t} /$ ha (T2)

- Lifos $25.5 \mathrm{t} /$ ha (T3)

- Control (T4) 
Vegetative apple-tree rootstocks of differing vigor M9, M26 and MM106 were planted as test plants.

Trials were set up in three variants, each with three replicates, with two bases at each iteration, plus controls. Care, protection, irrigation and fertilization experiments were uniform in all iterations and variants.

After the experiment, substitutional acidity in soil $\mathrm{pH} \mathrm{M} \mathrm{KCl}$ was performed (in suspension 1: 2.5, electrometric) and measurements were made of the assimilation leaf surface, vegetative growth and diameter of the aboveground part of the rootstock.

Statistical analysis of the results was performed by analysis of variance, and significant differences were found by LSD test.

\section{Results and Discussion}

Given the extremely high soil acidity of the soils $(\mathrm{pH} / \mathrm{KCl} 3.12)$, after treatment with lime materials, the soil $\mathrm{pH}$ was checked, and the data showed that acidity decreased in all variants. The highest $\mathrm{pH}$ value was determined in treatment with $\mathrm{CaO}(\mathrm{pH} / \mathrm{KCl} 4: 08)$, followed in declining order by lifos $(\mathrm{pH} /$ $\mathrm{KCl} 3.67)$ and bentonite $(\mathrm{pH} / \mathrm{KCl} 3: 59)$, which are still very low values, but changes in acidity were found by Bošković Rakočević et al. (2003).

\section{The effect of treatment on the leaf assimilating surface area}

Research results on the effect of different agents used to neutralize soil acidity on the size of the leaf assimilating surface area in apple rootstocks are given in Table 1.

Table 1. The effect of treatment on the leaf assimilating surface area

\begin{tabular}{ccccc}
\hline & \multicolumn{4}{c}{ Rootstock } \\
Treatments & M9 & M26 & MM106 & Average \\
\hline $\mathrm{T}_{1}$ & 25.91 & 21.39 & 25.68 & 24.33 \\
$\mathrm{~T}_{2}$ & 20.54 & 18.92 & 24.65 & 21.37 \\
$\mathrm{~T}_{3}$ & 25.25 & 19.55 & 26.36 & 23.72 \\
$\mathrm{~T}_{4}$ & 19.73 & 16.00 & 17.19 & 17.64 \\
Average & 22.85 & 18.96 & 23.47 & \\
\hline
\end{tabular}

$$
\begin{aligned}
& \operatorname{LSD}_{0.05}=16.25 \\
& \operatorname{LSD}_{0.01}=24.61
\end{aligned}
$$

The analysis of the results shows that the highest leaf assimilating surface area was formed in treatment with $\mathrm{CaO}$ (T1), followed by treatment with lifos 
(T3), and the control (T4). As shown by the statistical analysis, no statistically significant differences were observed between the surface M9 and MM106, while in relation to the base M26 the differences were statistically significant.

\section{The effect of treatment on vegetative growth}

The results (Tab. 2) show that the greatest vegetative growth was obtained under $\mathrm{CaO}$ treatment i.e. an average $152.3 \mathrm{~cm}$, which was a $64.1 \mathrm{~cm}$ increase relative to the control, and the increase was statistically significant. The weakest effect was achieved by the use of bentonite (average $93.8 \mathrm{~cm}$ ), which was an increase of only $5.6 \mathrm{~cm}$ compared to the control, but without statistical significance.

Table 2. The effect of treatment on vegetative growth

\begin{tabular}{ccccc}
\hline & \multicolumn{5}{c}{ Rootstock } \\
Treatments & M9 & M26 & MM106 & Average \\
\hline $\mathrm{T}_{1}$ & 129.5 & 168.8 & 158.5 & 152.3 \\
$\mathrm{~T}_{2}$ & 103.8 & 99.2 & 78.4 & 93.8 \\
$\mathrm{~T}_{3}$ & 104.5 & 112.0 & 137.9 & 118.1 \\
$\mathrm{~T}_{4}$ & 94.3 & 77.0 & 93.4 & 88.2 \\
Average & 108.0 & 114.2 & 117.1 & \\
\hline
\end{tabular}

$$
\begin{aligned}
& \operatorname{LSD}_{0.05}=16.25 \\
& \operatorname{LSD}_{0.01}=24.61
\end{aligned}
$$

The comparison of the tested rootstocks shows that although they differ in vigor, there are no statistically significant differences in vegetative growth. However, the interaction between the vegetative surface and lime material showed statistically significant differences in the application of $\mathrm{CaO}$ and lifos compared to all other treatments.

\section{The effect of treatment on the diameter of the aboveground part of the} rootstock

The diameter of the aboveground part of the rootstock was measured at a height of $15 \mathrm{~cm}$ above the surface. As with the previously analyzed parameters, better effects on the diameter of the aboveground part of the rootstock were obtained by the use of $\mathrm{CaO}(12.3 \mathrm{~mm})$, and the same average value was determined after lifos application (Tab. 3). Statistical analysis revealed a highly significant difference between the acidity neutralizing agents, while the rootstock had no significant influence. 
Table 3. The effect of treatment on the diameter of the aboveground part of the rootstock

\begin{tabular}{ccccc}
\hline Treatments & M9 & $\begin{array}{c}\text { Rootstock } \\
\text { M26 }\end{array}$ & MM106 & Average \\
\hline $\mathrm{T}_{1}$ & 11.6 & 12.7 & 12.5 & 12.3 \\
$\mathrm{~T}_{2}$ & 10.6 & 12.3 & 12.2 & 11.7 \\
$\mathrm{~T}_{3}$ & 12.6 & 12.6 & 11.7 & 12.3 \\
$\mathrm{~T}_{4}$ & 11.4 & 9.4 & 10.1 & 10.3 \\
Average & 11.5 & 11.7 & 11.6 & \\
\hline
\end{tabular}

$\operatorname{LSD}_{0.05}=0.53$

$\operatorname{LSD}_{0.01}=0.81$

\section{Conclusion}

The research results suggest the following:

Upon completion of the experiment, the maximum $\mathrm{pH}$ value of the soil was in the treatment with $\mathrm{CaO}$ (4.08), followed by lifos (3.67) and bentonite (3:59) applications.

The highest assimilating surface area of the leaf was obtained under $\mathrm{CaO}$ treatment, lifos and bentonite had weaker effects, and the lowest surface area was found in the control.

Maximum vegetative growth was achieved after $\mathrm{CaO}$ treatment.

The diameter of the aboveground part of the rootstock was the same in treatments with $\mathrm{CaO}$ and lifos, and somewhat lower after bentonite application.

Among the lime materials used, the best effect on all tested parameters was achieved by $\mathrm{CaO}$ treatment.

All agents used to neutralize soil acidity showed a positive effect on the test parameters in vegetative rootstocks for apple. This indicates the need to increase the $\mathrm{pH}$ value of the soil to ensure the production of quality planting material. 


\section{References}

Bošković Rakočević Lj., Bokan N. (2002): Mogućnosti rešavanja problema kiselih zemljišta i toksičnosti aluminijuma. Eko-konferencija, Tematski zbornik, Novi Sad, 113-118.

Bošković Rakočević Lj., Jakovljević M., Ubavić, M., Milivojević J. (2003): The Changes in Soil Acidity Depending on Amelioration Measures. Journal of Agricultural Sciences, 48(2): 149-158.

Dugalić, G. (1997): Karakteristike Kraljevačkog pseudogleja i iznalaženje mogućnosti za povećanje njegove produktivne sposobnosti. Doktorska disertacija, Poljoprivredni fakultet, Zemun.

Lučić, P., Đurić, G., Mićić, N. (1996): Voćarstvo. Nolit-Partenon, Beograd.

Narro, L. A., Perez, C. J., Pandey, S., Crossa, J., Salazar, F., Arias, P. M. (2001): Implications of soil-acidity tolerant maize cultivars to increase production in developing countries. In: N. Ae et al. (ed.). Plant nutrient acquisition: New perspectives. NIAES series 4. Springer Verlag, Japan, 447-463.

Radanović, D., Predić, T. (1997): Primeri toksičnosti Al i Mn na usevima pšenice i ječma na distričnom pseudogleju i degradiranom smeđem zemljištu. IX Kongres JDPZ "Uređenje, korišćenje i očuvanje zemljišta", Zbornik radova, Novi Sad, 235-243.

Sumner, M. E. (2004): Food production on acid soils in the developing world: problems and solutions. Proceedings of the 6th International Symposium on Plant-Soil Interactions at Low pH (Editors: Matsumoto H. et al.), August 1-5, Sendai, Japan, 2-3.

Ubavić, M., Kastori, R., Oljača, R., Marković, M. (2001): Ishrana voćaka. Naučno voćarsko društvo Republike Srpske i Poljoprivredni fakultet u Banjaluci, Banjaluka. 


\title{
TOLERANTNOST VEGETATIVNIH PODLOGA ZA JABUKU NA POVEĆANU KISELOST ZEMLJIŠTA
}

\author{
Gorica Paunović, Ljiljana Bošković-Rakočević, Radmila Ilić
}

Agronomski fakultet, Univerzitet u Kragujevcu, Srbija

\begin{abstract}
Rezime
Usvajanje hranljivih materija iz zemljišta od strane korenovog sistema voćaka ne zavisi samo od snabdevenosti zemljišta tim elementima, oblika u kome se oni nalaze, već i od reakcije sredine, tj. pH zemljišta. Poslednjih godina sve prisutniji problem u voćarskoj proizvodnji jeste pojava acidifikacije zemljišta, koja ima za posledicu povećanje sadržaja $\mathrm{H}, \mathrm{Al}$, Fe i Mn jona u adsorptivnom kompleksu zemljišta. Kisela zemljišta ograničavaju izbor voćnih vrsta i sorti koje se na njima mogu uspešno gajiti, pa je potrebno ispitivati tolerantnost i podloga $i$ sorti na povećanu kiselost zemljišta.U cilju neutralizacije kiselosti i toksičnosti aluminijuma, potrebno je pronaći sredstva za njihovo neutralisanje i na taj način ponovo osposobiti zemljište za uspešnu voćarsku proizvodnju. U tu svrhu primenjeni su sledeći krečni materijali: $\mathrm{CaO}$, bentonit i lifos. Kao test biljke zasađene su vegetativne podloge za jabuku različite bujnosti: M9, M26 i MM106, koje su u proizvodnoj praksi najčešće korišćene. Dejstvo krečnih materijala je ispitivano u odnosu na asimilacionu površinu lista, vegetativni porast i prečnik nadzemnog dela korišćenih podloga. Najbolji efekat u popravci zemljišta postignut je uz pomoć $\mathrm{CaO}$, nešto slabiji korišćenjem lifosa, a najslabiji primenom bentonita.
\end{abstract}

Ključne reči: $\mathrm{pH}$ zemljišta, mobilni Al, vegetativne podloge za jabuku, krečni materijali. 